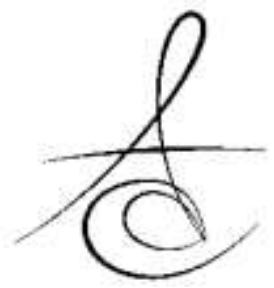

\title{
CONGENITAL DENTAL ANOMALIES IN THE PRIMARY DENTITION
}

\author{
SÜT DİŞİ DENTİSYONUNDA GÖRÜLEN DİŞ ANOMALİLER
}

Doç. Dr. Gülser KILINÇ*

Dt. Müjdet ÇETİN**

Makale Kodu/Article code: 3936
Makale Gönderilme tarihi: 19.12 .2018
Kabul Tarihi: 31.07 .2019

DOI : $10.17567 /$ ataunidfd.599421
Gülser Kılınç: ORCID ID: 0000-0002-7422-0482

Müjdet Çetin: ORCID ID: 0000-0001-6077-5578

\begin{abstract}
Aim: The purpose of this study was to investigate the prevalence of congenital anomalies in the primary dentition in preschool children populations.

Material and Methods: Data pertaining to a total of 935 children (487 boys and 448 girls) in the 2-5 year age-group who visited the Department of Pedodontics Clinic at the Dokuz Eylul Univeristy Hospital, Izmir, Turkey between january 01, 2016, and december 31, 2017 were all panoramic radiographs and photograph restrospectively analyzed. The presence of hypodontia, hyperdontia (supplemental and mesiodens), and double teeth (fusion and gemination) were recorded. Statistical analysis was performed using Fisher's exact test and chi-square test.

Results: Dental anomalies were found in $2.7 \%$ of children. Double teeth were the most frequently observed anomaly $(1.4 \%)$, followed by hyperdontia $(0.9 \%)$ and hypodontia $(0.5 \%)$. Unilateral missing teeth were more frequently observed than bilateral missing teeth. All supernumerary teeth were located in the primary maxillary incisor area. Dental anomalies were significantly more frequent $(\mathrm{p}=0.001)$ in boys $(1.6 \%, \mathrm{n}=15)$ as compared to that in girls $(1.1 \%, \mathrm{n}=10)$. Radiographic examination showed $36.0 \%$ of the patients ( 9 children) had anomalies in the permanent dentition.

Conclusions: Identification of primary dental anomalies at an early age is of great importance as it may help prevent malocclusions as well as functional and psychological problems. Anomalies in primary dentition exhibited a correlation with anomalies in permanent dentition.
\end{abstract}

Keywords: Hyperdontia, hypodontia, primary tooth, tooth abnormalities.

öz

Amaç: Bu çalışmanın amacı, okul öncesi çocukların süt dişinde görülen konjenital dental anomali prevalansını saptamaktır.

Gereç ve Yöntem: İzmir Dokuz Eylül Üniversitesi Tıp Fakültesi Çocuk diş kliniğine 01.01.2016-31.12.2017 tarihleri arasında gelen ve 2-5 yaş aralığında olan 935(487 erkek ve $448 \mathrm{kIz}$ ) hastanın panoromik filmleri ve fotoğrafları retrospektif olarak değerlendirilmiştir. Hipodonti, hiperdonti (supplemental, meziodens), ve ikiz diş (füzyon, geminasyon) varlığı tespit edilmiştir. Verilerin istatistik analizinde Fisher's exact test ve ki-kare testi kullanılmışır.

Bulgular: Dental anomali oranı \%2.7 olarak saptanmıştır. En yaygın görülen diş anomalisi ikiz diş(\%1.4), olarak bulunmuş olup, bunu hiperdonti $(\% 0.9)$ ve hipodonti $(\% 0.5)$ izlemiştir. Tek taraflı hipodonti çift taraflıdan daha fazla görülmüştür. Süt dişi dentisyonunda de görülen tüm supernumerer dişler üst çene keser dişler bölgesindedir. Diş anomalileri erkeklerde $(\% 1.6, n=15)$, kızlardan(1.1\%, $n=10)$ daha fazla görülmüş olup, fark istatistiksel olarak anlamlı bulunmuştur( $p=0.001)$. Radyolojik inceleme sonucunda süt dişinde diş anomalisi görülen hastaların \%36.0"sının(9 hasta) daimi dișlerinde de görülmüştür.

Sonuç: Süt dişi diş anomalilerin erken yaşta tespit edilmesi hastanın okluzyon bozukluklarının önlenmesinin yanı sıra, psikolojik ve fonksiyonel problemlerinin önlenmesinde de oldukça önemlidir. Ayrıca süt dişi dentisyonunda görülen diş anomalileri daimi dentisyonu da etkilemektedir.

Anahtar kelimeler: Diş anomalileri, hiperdonti, hipodonti, süt dişi.

\footnotetext{
${ }^{*}$ Dokuz Eylul University Vocational School of Health Services Oral and Dental Clinical Assistant Program

${ }^{* *}$ Dokuz Eylul University Hospital, Pediatric Dentistry Clinic Inciralti, Izmir.
} 


\section{INTRODUCTION}

As in permanent dentition, dental anomalies in size, form, and number variances can be observed in primary dentititon. ${ }^{1-4}$ Dental anomalies are usually detected during routine dental controls owing to an obvious deviation of the midline, malocclusion, rampant caries or due to the associated esthetic problems. ${ }^{3}$ The prevalence of dental anomalies is also an important data in the genetical studies. ${ }^{1,3}$ Dental anomalies in primary dentition may be a cause of either an isolated abnormality or a part of various syndromes. In epidemiological studies, it is important to differentiate dental anomalies that occur as part of syndromes. ${ }^{2}$

Dental anomalies in form and in number observed in primary dentition may also affect permanent dentition. ${ }^{5}$ Early diagnosis is particularly important for long-term treatment planning. Various studies have reported higher prevalence of anomalies of permanent dentition as compared to those of primary dentition. ${ }^{3,6}$ Reported prevalence rates of anomalies of primary dentition have ranged between $1.3 \%-7.2 \% .^{1-4,7}$ Although the etiology of dental anomalies is not known, factors like gender, race, and environmental conditions are considered to have a significant influence. ${ }^{1-4}$ Dental anomalies of primary dentition include hyperdontia (supernumerary teeth), double teeth (fusion, gemination), and hypodontia. ${ }^{5}$

Hyperdontia or supernumerary refers to the presence of one or more extra teeth is present than expected number of teeth. A supernumerary tooth with a normal form is called supplemental tooth, that with an atypical form (conical, tuberculate, or molariform shaped crown) is called mesiodens tooth. ${ }^{4,8}$ Although the etiology of supernumerary teeth is not exactly known, a split in the tooth germ or extra budding of the dental lamina is thought to be the pathogenetic mechanism. ${ }^{9,10}$

The prevalence of supernumerary teeth tends to vary in different populations; prevalence rates of $1 \%-3.6 \%$ for permanent dentition and $0.05 \%-0.8 \%$ for primary dentition have been reported. ${ }^{11-14}$ Various studies demonstrated that supernumerary teeth found by 2:1 at boys than girls and also more at maxillary region than mandibulary. ${ }^{5,11}$

Supernumerary teeth in primary dentition are generally found in premaxillary region. However, irrespective of the involved region, supernumerary teeth affect facial esthetics, and may cause unerupted incisiors, positional defects, rotation, midline diastema, delay in permanent teeth eruption, dentigerous or primordial cyst formation, root resorption of adjacent teeth, and orthodontic problems. Hence, it is essential to detect them at an early stage of development. ${ }^{13}$

The term "double teeth" is used for adjacent or twin teeth formations. Despite their similar clinical presentation, fusion and gemination are two different dental anomalies. While gemination is caused by the division of a single tooth bud, fusion is recognized as a developmental anomaly caused by the union of two separate tooth buds. ${ }^{6}$

In case of gemination, two teeth are formed from one single bud. Although no supernumerary tooth is observed in this case, the tooth crown tends to be larger. Fusion is recognized by the missing teeth. Both fusion and gemination may affect primary and permanent dentition. ${ }^{6}$

The etiology of fusion is not completely understood. ${ }^{15}$ It is thought to result from fusion of two teeth prior to their calcification due to some physical trauma or pressure that brings this in close apposition to each other. In this case two teeth become a very large single tooth. If they fuse after the completion of the teeth crown, only one large root is observed. In either case dentine is always affected. Teeth may also have one single or two separate root canals. The fusion may happen either between two normal teeth or one single normal and one surnumerary tooth. ${ }^{6}$ The reported prevalence of double teeth in primary and permanent dentition is $0.5 \%, 1.5 \%$, and $0.1 \%$, respectively. ${ }^{15,16}$ Studies have shown that the prevalence of double teeth in Asian countries is significantly higher than that in European and North American countries. ${ }^{15,16}$

The absence of one or more teeth is called as hypodontia. ${ }^{1,3}$ Hypodontia in primary teeth is typically followed by hypodontia in the permanent teeth. Early diagnosis of hypodontia will help to plan adequate dental treatment. It is also essential to inform the families accordingly. ${ }^{1,2}$ The prevalence of hypodontia in primary dentition ranges from $0.2 \%-2.3 \% .{ }^{1-4}$

The objective of this study was to evaluate the prevalence of dental anomalies (supernumerary teeth, double teeth, hypodontia) of primary dentition in children aged $2-5$ years.

\section{Subjects and Methods}

The study was approved by the Dokuz Eylul University Noninvasive Clinical Research Ethics committee (protocol number: 2325-GOA and decision number: 2015/24-10). 


\section{Sample}

The present study was conducted among children in the age-group of 2-5 years who visited child dental clinic at the Dokuz Eylül university hospital between January 01.2016 and December 31, 2017 Out of a total of 935 children, those who had supernumerary teeth (mesiodens, suplemental), double teeth (fusion and gemination) and hypodontia were eligible for this study. Dental anomalies were examined in all primary teeth in the mouth. All children photographs and radiographs were examined by a pedodontist. The same criteria were used to diagnose dental anomalies in the permanent dentition analyzed on the panoramic radiographs. Healthy children with primary dentition, who had no history of tooth loss due to trauma or extraction, were enrolled in this study. Children with systemic disease, chronic use of medication and those with cleft lip and/or cleft palate were excluded.

\section{Dental anomalies}

The entire maxillary and mandibular arches were examined. Three anomalies, supernumerary teeth, hypodontia and double teeth were recorded in primary dentition. Dental anomalies including variations in tooth size, morphology, and number were recorded according to the criteria described by Kreiborg et al. ${ }^{17}$ (Table 1). The anomalies in number of teeth (supernumerary teeth and hypodontia) were determined by counting the number of teeth on dental arch, while morphological anomalies (double teeth) were determined by the number and appearance of the teeth. Additionally, data on sex and the specific affected site on the dental arc was examined.

Table 1. Dental anomalies representing variations in tooth size, morphology, and number

were recorded according to the criteria described by Kreiborg et al. ${ }^{17}$

\begin{tabular}{|c|l|l|}
\hline \multicolumn{2}{|c|}{ Hypodontia } & $\begin{array}{l}\text { Absence of one or only a } \\
\text { few teeth }\end{array}$ \\
\hline $\begin{array}{c}\text { Hyperdontia } \\
\text { (Supernumerar) }\end{array}$ & Mesiodens & $\begin{array}{l}\text { Supernumerary tooth present } \\
\text { in the pre-maxilla between } \\
\text { the two central incisors }\end{array}$ \\
\cline { 2 - 3 } & Supplemental & $\begin{array}{l}\text { An additional tooth to the } \\
\text { normal series which } \\
\text { resembles the tooth with } \\
\text { which it is associated }\end{array}$ \\
\hline \multirow{3}{*}{ Double teeth } & Fusion & $\begin{array}{l}\text { Union in dentin and/or } \\
\text { enamel between two or more } \\
\text { separately developed normal } \\
\text { teeth }\end{array}$ \\
\hline & Gemination & $\begin{array}{l}\text { Incomplete division of a tooth } \\
\text { germ }\end{array}$ \\
\hline
\end{tabular}

\section{Statistical analysis}

All data analyses were performed with Statistical Package for Social Sciences (SPSS) for Windows 20.0 software program (SPSS Inc., Chicago, $\mathrm{IL}$, USA). Descriptive analysis was performed to evaluate the frequency of dental anomalies. Chisquared and Fisher exact test were used to assess the association of age, sex and geographical religion with prevalence of dental anomalies in study subjects. A significance level of $p<0.05$ was adopted.

\section{RESULTS}

Out of 935 children in the 2-5 years age-group with primary dentition, 487 (52.1\%) were boys and $448(47.9 \%)$ were girls. Anomalies were observed in 25 children, which corresponded to an overall prevalence of $2.7 \%$ (Table 2). Radiographic examination showed $36.0 \%$ of the patients ( 9 children) had anomalies in the permanent dentition. Twenty three children had unilateral, while two children had bilateral primary teeth anomalies. A fusion on the right and a hypondia on the left of the mandubular was found in one child with bilateral primary teeth anomaly (Table 3 ). Left and right hypondia were found in maxillary lateral incisors of the second child. Pictures of inner mouth, intra-oral radiograph and panoramic radiograph of the patients who had clinical primary dentititon anomalies were evaluated (Fig.1,2). Dental anomalies were significantly more frequent $(p<0.001)$ in boys $(1.6 \%$, $\mathrm{n}=15)$ than in girls $(1.1 \%, \mathrm{n}=10)$. While dental anomaly is not seen at the age of 2 , this rate increased to $0.3 \%$ at the age of 3 years, $1.2 \%$ at the age of 4 years and $1.3 \%$ at the age of 5 years.

Table 2. Distribution of dental anomalies by sex and age (Unit of analysis: Children and Teeth)

\begin{tabular}{|c|c|c|c|c|}
\hline \multicolumn{2}{|c|}{} & N (\%) & $\begin{array}{c}\text { Children N } \\
(\%)\end{array}$ & $\begin{array}{l}\text { Teeth n } \\
(\%)\end{array}$ \\
\hline \multirow{3}{*}{ Sex } & Female & $448(47.9)$ & $10(1.1)$ & $10(1.1)$ \\
\cline { 2 - 5 } & Male & $487(52.1)$ & $15(1.6)^{*}$ & $17(1.8)^{*}$ \\
\hline & Total & 935 & $25(2.7)$ & $27(2.9)$ \\
\hline \multirow{3}{*}{ Age } & 2 & $46(4.9)$ & - & - \\
\cline { 2 - 5 } & 3 & $135(14.4)$ & $3(0.3)$ & $4(0.4)$ \\
\cline { 2 - 5 } & 4 & $348(37.2)$ & $10(1.1)$ & $11(1.2)$ \\
\cline { 2 - 5 } & 5 & $406(43.4)$ & $12(1.3)$ & $12(1.3)$ \\
\hline
\end{tabular}

$N$, number of children examined $n$, number of children with dental anomalies.

${ }^{*} p$ value: chi-squared test. $(p<0.05)$ 


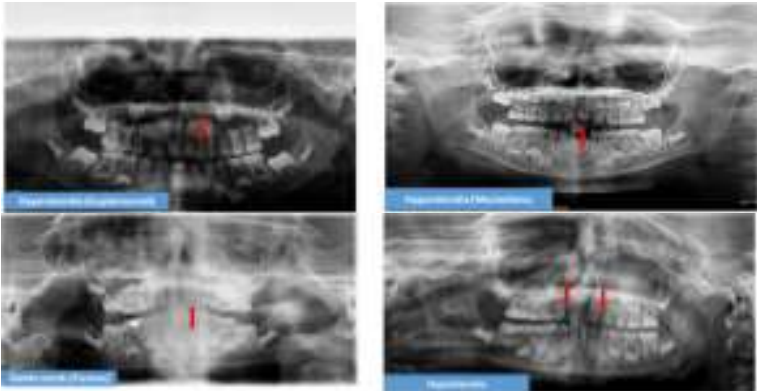

Figure 1: Panoramic radiograph of the child in showing hyperdontia (supplemental) primary maxillary left lateral incisor. Panoramic radiograph of the child in showing hyperdontia (meziodens) primary maxillary incisors. Panoramic radiograph of the child in Double teeth (fusion) involving primary maxillary incisor region and showing agenesis of the permanent maxillary lateral incisors. Panoramic radiograph of the child in showing bilateral tooth agenesis of the primary maxillary lateral incisors and permanent maxillary lateral incisors.

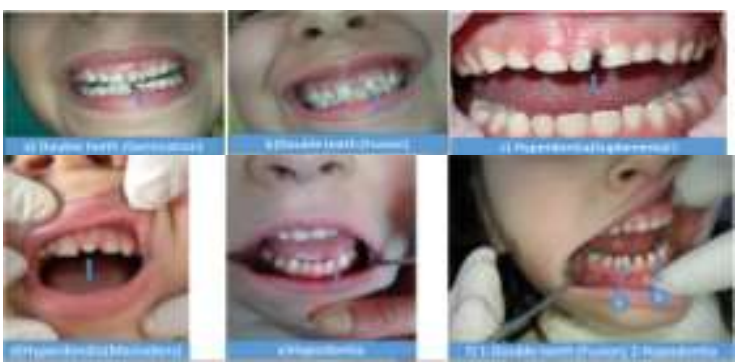

Fig. 2 a) Double teeth (gemination) involving primary maxillary incisors region. b) Double teeth (fusion) involving primary maxillary incisors region and tooth agenesis of the lateral incisor. c) Hyperdontia (supplemental) involving primary maxillary central incisors region. d) Hyperdontia (meziodens) involving primary maxillary central incisors region. e) Unilateral tooth agenesis of the primary maxillary lateral incisor region. f) Double teeth involving primary mandibular right incisor/canine region and tooth agenesis of the contralateral incisor.

Double teeth were the most frequently observed anomaly (1.4\%), followed by hyperdontia $(1.0 \%)$, and hypodontia (0.5\%). Unilateral missing teeth were more frequently observed than bilateral missing teeth. Dental anomalies in maxilla $(2.0 \%)$ were significantly more frequent than those in mandile $(0.9 \%)(p<0.001)$. All supernumeray teeth were found in maxilla $(1.0 \%)(p<0.001)$, and mesiodens $(0.6 \%)$ were more frequently observed than suplementals $(0.3 \%)$. Hyperdontia were significantly more frequent $(p<0.001)$ in boys than in girls. Mesiodens cases $(0.6 \%)$, early loss of the primary maxillary central incisor or its luxation was observed. The suplemental teeth in primary dentition were single and located in the lateral incisor region in maxilla. The mesiodens teeth in primary dentition were located in the central incisor region in maxilla. No anomaly was observed in the permanent dentition following the case of maxillar suplemental and mesiodens teeth (Table 4). All children with tooth agenesis in the primary dentition also showed agenesis of the permanent dentition. Patients with hypodontia in the primary dentition, in our study, displayed hypodontia in the permanent dentition in $100 \%$ ( 3 children) of the cases. In all cases of tooth agenesis in the primary dentition, the missing tooth was the lateral incisor.

Double teeth and hypodontia were detected in both maxilla and mandible with no significant between-group difference. Double primary teeth were found mostly in the maxilla $(61.5 \%)$. In all three patients, while fusion on maxilla is formed involving cental and lateral incisors, on mandible it is formed involving the lateral incisors and canines. Approximately $46.2 \%$ of cases experienced further problems in the permanent successors.

Table 3. Distribution of dental anomalies by sex and dental arch

\begin{tabular}{|c|c|c|c|c|c|c|c|}
\hline \multirow{2}{*}{$\begin{array}{c}\text { Unit of } \\
\text { analysis } \\
(\%)\end{array}$} & \multirow[t]{2}{*}{ N (\%) } & \multirow[t]{2}{*}{ n (\%) } & \multicolumn{2}{|c|}{ Hyperdontia } & \multicolumn{2}{|c|}{ Double teeth } & \multirow{2}{*}{$\begin{array}{c}\text { Hypodon } \\
\text { tia }\end{array}$} \\
\hline & & & Meziodens & Suplemental & Fusyon & Gemination & \\
\hline $\begin{array}{c}\text { Children(N) } \\
\text { Teeth(n) }\end{array}$ & $25(2.7)$ & $27(2.9)$ & $6(0.6)$ & $3(0.4)$ & $6(0.6)$ & $7(0.8)$ & $5(0.5)$ \\
\hline \multicolumn{8}{|l|}{ Sex } \\
\hline Female & $10(1.1)$ & $10(1.1)$ & $1(0.1)$ & - & $1(0.1)$ & $5(0.6)$ & $3(0.3)$ \\
\hline Male & $15(1.6)^{*}$ & $17(1.8)^{*}$ & $5(0.5)$ & $3(0.4)$ & $5(0.5)$ & $2(0.2)$ & $2(0.2)$ \\
\hline \multicolumn{8}{|l|}{ Arch } \\
\hline Upper & $18(1.9)^{*}$ & $19(2.0)^{*}$ & $6(0.6)^{*}$ & $3(0.3)^{*}$ & $3(0.3)$ & $5(0.5)$ & $2(0.2)$ \\
\hline Lower & $7(0.8)$ & $8(0.9)$ & - & - & $3(0.3)$ & $2(0.2)$ & $3(0.3)$ \\
\hline Unilateral & $23(2.5)^{*}$ & $23(2.5)^{*}$ & $6(0.6)$ & $3(0.3)$ & $5(0.5)$ & $7(0.8)$ & $2(0.2)$ \\
\hline Bilateral & $2(0.2)$ & $4(0.4)$ & - & - & $1(0.1)$ & - & $3(0.3)$ \\
\hline
\end{tabular}

N: The number of children with dental anomalies n: The number of teeth with dental anomalies *Fisher exact test: $p<0.001$.

Table 4. Anomalous primary teeth and its effect on permanent teeth

\begin{tabular}{|l|l|l|l|}
\hline Anomaly & $\begin{array}{l}\text { No of childrens } \\
\text { with } \\
\text { anomalies in }\end{array}$ & $\begin{array}{l}\text { No of children } \\
\text { with anomalies } \\
\text { in the }\end{array}$ & $\begin{array}{l}\text { Degree of effect } \\
\text { (\%) }\end{array}$ \\
\hline Hyperdontia & 9 & - & - \\
\hline Double teeth & 13 & 6 & 46.2 \\
\hline Hypodontia & 3 & 3 & 100.0 \\
\hline Total & 25 & 9 & 36.0 \\
\hline
\end{tabular}

\section{DISCUSSION}

Hyperdontia, hypodontia and double teeth seen in primary dentition may also be present in permanent dentition. $3,5,13,18,19$ Studies performed on primary dentition show a dental anomaly rate of $1.3 \%-7.2 \%$ (Table 5). ${ }^{1-3,5,7,17,20}$

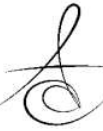


Table 5. Prevalence of dental anomalies of primary dentition in different geodemographic regions

\begin{tabular}{|c|c|c|c|c|c|}
\hline $\begin{array}{c}\text { Referenc } \\
\text { e N(\%) }\end{array}$ & $\begin{array}{c}\text { Country } \\
\text { (n) }\end{array}$ & $\begin{array}{r}\text { Hyper } \\
\text { donti }\end{array}$ & $\begin{array}{l}\text { Dou } \\
\text { ble }\end{array}$ & $\begin{array}{c}\text { Hypod } \\
\text { ontia }\end{array}$ & $\begin{array}{l}\text { Ove } \\
\text { rall }\end{array}$ \\
\hline Chen et & Taiwan(2 & 1.0 & 3.0 & 2.0 & 5.0 \\
\hline Deolia et & India & 0.3 & 2.3 & 0.6 & 4.0 \\
\hline Gomes et & Brazil & 0.3 & 1.0 & 0.3 & 1.8 \\
\hline Kapdan & Turkey(11 & 0.3 & 1.3 & 0.2 & 2.0 \\
\hline Mukhopa & Bengali & 0.4 & 0.4 & 0.5 & 1.8 \\
\hline Kramer & Brazil(126 & 0.3 & 1.3 & 0.6 & 2.5 \\
\hline Carvalho & Belgian & 0.8 & 0.7 & 0.4 & 1.8 \\
\hline Yonezu et & Japanese( & 0.007 & 4.1 & 2.4 & 7.2 \\
\hline Magnuss & Iceland(9 & 0.5 & 0.7 & 0.5 & 1.7 \\
\hline Whittingt & New & 0.2 & 0.8 & 0.3 & 1.4 \\
\hline King et & Chines & 2.8 & 4.1 & 4.1 & 6.3 \\
\hline Järvinen & Finland & 0.4 & 0.7 & 0.9 & 1.3 \\
\hline Jones et. & USA (493) & 0.2 & 0.4 & - & - \\
\hline $\begin{array}{l}\text { Present } \\
\text { study }\end{array}$ & $\begin{array}{l}\text { Turkey } \\
\text { (935) }\end{array}$ & 1.0 & 1.4 & 0.5 & 2.7 \\
\hline
\end{tabular}

In this study, a total of 27 (2.9\%) dental anomalies in $25(2.7 \%)$ children pertained to primary dentition. The prevalence of dental anomalies observed was higher than that reported in some studies, $^{3-5,18,20,21}$ and lower than that reported in some of the others; $1,2,22$ however, it was very close to that reported by Kramer et al. ${ }^{7}(2.5 \%)$. This difference in prevalence of primary dentition dental anomalies may be attributable to differences in sample size, ethical and genetical differences. Moreover, the clinical studies have reported higher prevalence rates than those reported by studies perfomed in schools and other places. ${ }^{4}$

We found a higher prevalence of dental anomalies among boys (1.6\%) as compared to that in girls $(1.1 \%)$. While some earlier studies found no statistically significant difference between boys and girls, ${ }^{1,3,5}$ some others have reported a higher prevalence of dental anomalies among girls. ${ }^{6}$ Kapdan et al. ${ }^{4}$ and Whittington et al. ${ }^{21}$ reported a higher prevalance of dental anomalies in primary dentition in boys as compared to that in girls, which is consistent with our findings.

While Delio et al. $^{11}$ found most dental anomalies in children at the age of 3 year, we found that most anomalies in children at the age of 5 . This may be attributed to the high rate of mesiodens seen in this age group.

Hyperdontia teeth in primary dentition are rarer than that in permanent dentition. ${ }^{1,3,5,22}$ The prevalence in primary dentition varies between $0.07 \%$ $2.8 \% .13,4,19,22$ In the present study, the prevalence of hyperdontia was $1.0 \%$. Kapdan et al. ${ }^{4}$ found a lower hyperdontia prevalence $(0.3 \%)$ in their study on
Turkish children aged 2-5 years. The fact that this study was performed in a clinical setting, which included children showing mesiodens brought by their parents to the clinics likely contributed to the higher prevalence of dental anomalies.

As in the study of Mukhopadhyay et al. $^{5}$ mesiodens tooth was the most frequently seen hyperdontia in this study. However, in a study conducted on Japanese children with primary dentition by Miyoski et al. ${ }^{23}$ suplemental teeth between maxillary lateral incisors were the most frequent hyperdontia.

Permanent maxillary central incisors erupt between six and seven years of age. ${ }^{18}$ Before this period, in the absence of trauma, if a luxation occurs on left and/or right primary maxillary central incisor and if these teeth are lost earlier, the possibility of mesiodens might be checked by a dental radiographic of this location. In most of the mesiodens cases $(0.6 \%)$, early loss of the primary maxillary central incisor or its luxation was observed.

Parents usually do not recognize suplemental teeth; therefore, such teeth are typically detected during the routine dental controls. In a study by King et al. $^{22}$ supplemental teeth were found mainly between the maxillary lateral incisors. In the present study, three children had supplemental teeth and all were located in maxillary between the laterals. In this study, hyperdontia was more commonly found in boys as compared to that in girls, although the difference was not statistically significant. Mukhopadhyay et al. ${ }^{5}$ reported the same relation between hyperdontia and gender. Also, Kim et al. ${ }^{24}$ found mesiodens twice more frequently in boys as compared to that in girls.

While some researchers reported more frequent hypodontia in maxillary lateral incisors, $5,21,25$ others have found these more frequently in mandibular lateral incisors. ${ }^{22}$ In this study, hypodontia was observed both in maxilla and mandible; there was no significant difference in this respect. While bilateral hypodontia was found in three children, only one child showed maxillary unilateral hypodontia. In this study, all children had missing primary lateral teeth. The reported prevalence of hypodontia in primary dentition has ranged between $0.2 \%-4.1 \%$ in various pediatric populations. ${ }^{1,4,19,22}$ While the prevalence of hypodontia in the present study was $0.5 \%$, Chen et al. ${ }^{1}$ reported 2.0\% prevalence in Taiwanese children, Yanezu et al. ${ }^{18}$ reported a $2.4 \%$ prevalence in Japanese children, and King et al. $^{22}$ reported a $4.1 \%$ prevalence in Chinese children. In European populations, the 
reported prevalence has varied between 0.2 and $0.9 \%, 1,18,20,25$ which is closer to our findings. While many researchers, like in this study, found no significant relation between hypodontia and sex. . $^{1,23,25}$ King et al. ${ }^{22}$ reported higher prevalance in girls as compared to that in boys.

In the present study, all children (3 children) with hypodontia in the primary dentition demonstrated hypodontia in the permanent dentition. This was in agreement with the reports of Whittington et al. ${ }^{21}$ and Mukhopadhyay et al. ${ }^{5}$ who observed it in $100 \%$ of the cases.

Double tooth is observed more frequently in primary dentition $(0.4 \%-4.9 \%)$ as compared to that in permenant dentition $(0.1 \%)^{5,15,16,19,21,26}$ It is also more frequently found in Asia1 (2.3\%-4.1\%), 2,17,20 than in Europe $(0.7 \%-1.3 \%),{ }^{4,18,20,25}$ and USA (0.4\%) (24). In this study the prevalence of double teeth was $1.4 \%$, which is quite close to that reported in Turkish children $(1.3 \%)$ by Kapdan et al. ${ }^{4}$

So far, the etiology of double teeth is not known. Environmental factors, genetics, premature birth, trauma, and vitamin deficiency are thought to be involved in its causation. ${ }^{27-29}$

In primary dentition, early diagnosis of fusion and gemination is essential as it helps to identify potential problems and their treatment in permanent dentition. In most of the cases where a fusion is identified in primary dentition, a congenital missing tooth is observed in permanent dentition. ${ }^{21}$ However, in case of gemination, congenital missing teeth is not always present in permanent dentition. ${ }^{3,21}$ In this study, while all 6 children who presented fusion in primary dentition had congenital missing teeth in permanent dentition, none of the cases with gemination had a congenital permanent missing teeth. Several studies have shown that double primary teeth have an influence on permanent successors, including hypodontia, supernumerary teeth. ${ }^{3,5,13,29} \mathrm{Wu}$ et al. ${ }^{13}$ report, the influence of permanent successors was $55.9 \%$ when double primary teeth involved the lateral incisors and canines. In our study, the overall percentage of permanent tooth anomalies was $46.2 \%$.

Aguiló et al. ${ }^{30}$ in their study on primary dentition, reported double teeth both on left and right sides of maxilla and mandible without any statistically significant difference. Similarly in this study double teeth was found in both arches and no statistically significant difference was observed in the incidence of double teeth between maxilla and mandible. Association between gender and double teeth has not been reported. ${ }^{3,30}$ In the present study, too, no such association was observed. However, Yonezu et al. ${ }^{19}$ reported a higher prevalence of double teeth in mandible as compared to that in maxilla and a higher prevalence among girls than in boys.

This study was conducted in a university clinical setting, and the findings may not be representative of the prevalence of dental anomaly prevalence in the general population. Besides the retrospective study design does not allow for causal inferences.

\section{CONCLUSION}

Our findings are in line with most of the previous reports related to these dental anomalies in primary dentition and emphasize the encouragement of parents to bring their young children for regular dental examinations. Anomalies in the primary dentition are important because of their effect on the underlying permanent dentition. A careful and detailed examination by a specialist will certainly help to determine the problems at an early stage and allow for effective and long term treatment planning based on the child's age, gender and the location of the anomalies.

Financial support and sponsorship: Nil.

Conflict of Interest: The authors declare that there is no conflict of interest.

\section{REFERENCES}

1. Cox 1- Chen YH. Cheng NC, Wang YB, Yang CY. Prevalence of congenital dental anomalies in the primary dentition in Taiwan. Pediatr Dent 2010; 3: 525-9.

2. 2-Deolia SG, Chhabra C, Chhabra KG, Kalghatgi S, Khandelwal N. Dental anomalies of the deciduous dentition among Indian children: A survey from Jodhpur, Rajasthan. India. J Indian Soc Pedod Prev Dent 2015; 33: 111-5.

3. Gomes RR, Fonseca JA, Paula LM, Acevedo AC, Mestrinho HD. Dental anomalies in primary dentition and their corresponding permanent teeth. Clin Oral Invest 2014; 18: 1361-7.

4. Kapdan A, Kustarci A, Buldur B, Arslan D, Kapdan A. Dental anomalies in the primary dentition of Turkish children. Eur J Dent 2012; 6: 178-83.

5. Mukhopadhyay S, Mitra S. Anomalies in primary dentition: Their distribution and correlation with permanent dentition. J Nat Sci Biol Med 2014; 5: $139-43$ 
6. Bruce C, Manning-Cox G, Stanback-Fryer C, Banks K, Gilliam M. A radiographic survey of dental anomalies in Black pediatric patients. NDA J 1994; 45: 6-13.

7. Kramer PT, Feldens CA, Ferreira SH, Spiguel $\mathrm{MH}$, Feldens EG. Dental anomalies and associated factors in 2- to 5-year- old Brazilian children. Int J Paediatr Dent 2008; 18: 434-40.

8. Koparal M, Ünsal HY, Alan HT, Yalçın M, Ege B, Gülsün B. Güneydoğu Anadolu Bölgesi'nde yedi farklı dental anomalinin görülme sıklığı. Selcuk Dent J 2018; 5: 135-41.

9. Anthonappa RP, King NM, Rabie AB. Aetiology of supernumerary teeth: A literature review. Eur Arch Paediatr Dent 2013; 14: 279-88.

10. Koszowski R, Waśkowska J, Kucharski G, Śmieszek-Wilczewska J. Double teeth: evaluation of 10 -years of clinical material. Cent Eur J Med 2014; 9: 254-63.

11. Srivastava N, Srivastava V. An inverted supernumerary tooth: Report of case. ASDC J Dent Child 2001; 68: 61-2.

12. Venkataraghavan K, Anantharaj A, Nihal NK. Supplemental primary tooth: A review report of a rare occurrence. IJCDS 2011; 2: 48-51.

13. Wu CV, Lin YT, Lin YT. Double primary teeth in children under 17 years old and their correlation with permanent successors. Chang Gung Med J 2010; 33: 188-92.

14. Bayram M, Yıldırım M, Köse A, Seymen F. Pedodonti anabilim dalında başlangıç muayenesinde alınan panoromik radyografilerin değerlendirilmesi. İst Uni Diş Hek Fak Derg 2011;45:41-7.

15. Hamasha AA, Al-Khateeb T. Prevalence of fused and geminated teeth in Jordanian adults, Quintessence Int 2004; 35: 556-9.

16. Sekerci AE, Sisman Y, Yasa Y, Sahman H, Ekizer A. Prevalence of fusion and gemination in permanent theeth in Cappadocia region in Turkey. Pakistan Oral Dent J 2011; 31: 15-20.

17. Koch G, Paulsen S. Pediatric Dentistry: A Clinical Approach. 3 ed. Munksgaard; Copenhagen:1994. p. 275-292.

18. Carvalho JC, Vinker F, Declerck D. Malocclusion, dental injuries and dental anomalies in the primary dentition of Belgian children. Int J Paediatr Dent 1998; 8: 137-41.

19. Yonezu T, Hayashi Y, Sasaki J, Machida Y. Prevalence of congenital dental anomalies of the deciduous dentition in Japanese children. Bull
Tokyo Dent Coll 1997; 38: 27-32.

20. Magnusson TE, Hypodontia, hyperdontia, and double formation of primary teeth in Iceland. An epidemiological study. Acta Odontol Scand 1984; 42: 137-9.

21. Whittington BR, Durward CS. Survey of anomalies in primary teeth and their correlation with the permanent dentition. N Z Dent J 1996; 92: 4-8.

22. King NM, Tongkoom S, Wong HM. Morphological and Numerical Characteristics of the Southern Chinese Dentitions. Part III: Anomalies in the Primary Dentition. Open Anthropol J 2010; 3: 2536.

23. Miyoshi S, Tanaka S, Kunimatsu H, Murakami $Y$, Fukami Y, Fujisawa S. An epidemiological study of supernumerary primary teeth in Japanese children: A review of racial diff erences in the prevalence. Oral Dis 2000; 6: 99-102.

24. Kim SG, Lee SH. Mesiodens: A clinical and radiographic study. J Dent Child (Chic) 2003; 70: 58-60.

25. Järvinen S, Lehtinen L., Supernumerary and congenitally missing primary teeth in Finnish children. Acta Odont Scand 1981; 39: 83-6.

26. Jones ML, Mourino AP, Bowden TA. Evaluation of occlusion, trauma, and dental anomalies in AfricanAmerican children of metropolitan Headstart programs. J Clin Pediat Dent 1993; 18: 51-4.

27. Knezevic S, Travan Z, Tarle J, Sutalo B, Janković B, Ciglar I. Double tooth. Coll Antropol 2002; 26: 6672.

28. Kılınç G, Çetin M. Süt dişlerinde Süpernumerer diş (Suplemental diş) ve ikiz diş: İki olgu sunumu. Atatürk Üniv Diş Hek Fak Derg 2016;Supl 15:2630.

29. Aydinbelge $M$, Sekerci1 AE, Caliskan $S, H$ Gumus $\mathrm{H}, \quad \mathrm{Y}$ Sisman $\mathrm{Y}$, Cantekin K. Clinical and Radiographic Evaluation of Double Teeth in Primary Dentition and Associated Anomalies in the Permanent Successors. Niger J Clin Pract 2017; 20:847-51.

30. Aguiló L, Gandia JL, Cibrian R, Catala M. Primary double teeth. A retrospective clinical study of their morphological characteristics and associated anomalies. Int J Paediatr Dent 1999; 9: 175-83.

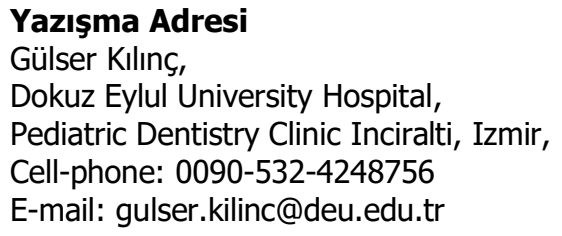

